\title{
Muslims in Academia. New Stakeholders, Old Institutions, and the Fu- ture of Western Islam
}

\author{
By Thomas Hoffmann
}

\section{Outlines of a Research Project}

\begin{abstract}
.
Based on the observation that a rising number of scholars and students with Muslim background study and teach Islamic studies in Western Europe and North America, we propose the following two broad hypotheses: 1) that this development within academia will bring about changes within the narrow confines of Academia, but 2) will also have wider implications for the development and formation of Islamic thinking/exegesis in Western Europe and North America and perhaps even core-Islamic countries in the Middle East and South East Asia. In order to understand and assess this new state of affairs and its prospects, we set out to identify and analyse the social, religious, national background and role of these new academic stakeholders, their relevant institutions, programmes, research themes and approaches, challenges and opportunities. Based on the premise that Islam is a religion with strong scripturalist roots (among other roots to be sure) we direct particular attention to that field within Islamic studies that deals specifically with Qur'an and hadith-related studies. This research project, then, investigates two questions. The first one is the most restricted and relates to organizational matters of the contemporary university (human resources, curriculum, funding etc.) and the Forschungsgeschichte and prospects of Islamic/Qur'ânic studies. The second question is more extensive in scope and probes grand-scale theological-exegetical trends, profiles and scenarios of a so-called Western Islam.
\end{abstract}

\section{General Research Framework}

The overall subject of this postdoctoral research project concerns the present state of affairs status of the canonical Islamic scriptures, i.e., the Qur'ân and hadîth-related literature, ${ }^{1}$ among scholars and students with Muslim background in the context of Western Europe and North America. The rationale behind this somewhat cumbersome adjectival add-on, i.e. 'with Muslim background', is a wish not to let these persons' professional identities become eclipsed by a religious label such as 'Muslim teachers.' Even the academic Muslim whose religious commitment is crucial to his or her identity will presumably prefer to be judged professionally according to academic, scholarly criteria. This, however, does not preclude that the academic Muslim construe his or her religious/ethnic background as an asset that can be utilized profitably in scholarly work.

The phrase 'state of affairs' should be taken to comprise the various exegetical approaches and theological debates that Muslims have partaken in during the past twenty years with regard to those indispensable bodies of texts - and have done so in a primarily European and North American settings. ${ }^{2}$ Exegetical in this sense comprises both highly specialized, textualist approaches and approaches that involve a broader theological out- 
look, often with markedly societal concerns (politically, legally). To identify, analyse, interpret and even envisage exegetical trends in relation to the European and North American context (and the Islamic world at large) therefore provides the general framework of the research project. It goes without saying that the identification of trends also demands attention to possible (or obvious) differences between these contexts, for instance, between a more northern-based European scientific agnosticism as against a more faith-based US setting, and the differences in socio-economic profiles between US and European Muslim citizens.

In terms of institutional setting and funding, the project forms part of a larger research programme going under the name The Centre for European Islamic Thought. Conducted under the aegis of Professor Jørgen S. Nielsen ${ }^{3}$ and funded by the Danish National Research Foundation/Danmarks Grundforskningsfond ${ }^{4}$ the centre is an attempt to keep the research community and the public up to date regarding Islamic thought in contemporary Europe and North America as well as conducting research in specific areas, such as that of the present project. The centre is funded until primo 2013.

From the 1990s and onwards Muslims in Western Europe and North America have gained momentum in the field of canonical exegesis and theological thinking. New voices and stances proliferate; new 'power-players' and interest groups engage the discursive field and traditional patterns of religious authority are questioned and reinvented. ${ }^{5}$ These new trends and profiles are reflected in academia, in the universities, which time and again provide the professional platforms necessary for the development, articulation, and dissemination of this thinking. This new development is partly a response to Muslims' new (i.e., post-WW II) Sitz im Leben in countries with a long Christian, Jewish, and humanistic/secular heritage, partly a result of initiatives originating in the heartlands of Islam, first and foremost the Greater Middle East. ${ }^{6}$

First, the programme focuses on the processes and circumstances under which these theological discourses unfold. Second, it seeks to locate and understand these processes and circumstances in the contexts of both the history of Islamic religious thought and of contemporary developments in Islamic thinking. Third, it will consider how these processes should be taken as more or less deliberate reactions to a new diaspora-based situation. Reactions that on one hand hold a restricted and geographically anchored context, 
namely that of Western Europe and North America, and reactions that on the other hand must be evaluated with reference to less clear-cut, albeit all-pervading factors, such as modernity, migration, globalization, and the knowledge society. A significant factor in this exegetical work-in-progress must be investigated from the perspectives of a minority and cultural Entfremdungs-situation vis-à-vis issues of secularization and non-Muslim majority societies. It is, however, important to issue a caveat regarding the tendency to confine this complex subject to questions fraught with the standard minority-majorityperspective; attention to intra-Muslim relations and the deployment of Islamic traditions is imperative as well. ${ }^{7}$

The first mission of the programme will be to identify systematically the universitybased producers of Islamic religious thinking in Europe and to relate them to their respective contexts, both in terms of educational institutions and background. This top-down orientated part of the programme will need not only to record but also to engage with these thinkers and institutions in face-to-face meetings and 'fieldwork.'

\section{Specific Research Focus: A New Academic Muslim Elite}

As part of this overall programme, we present a specific project, which concerns the changing role of secular, university-based education and research with regard to Islam (e.g., Islamic studies, Middle East studies, religious studies, and related disciplines), a changing role that partly must be explained with reference to the rising percentage of Muslim students and scholars. In short: a new demography of stakeholders. But the increasing Muslim-anchored patronage and funding of research and professorships will also be pivotal to the project. ${ }^{8}$ It is an attempt to provide attention to a research field that has been neglected for a long time, but now seems to attract attention both scholarly and politically, with articles, conference proceedings, and governmental reports coming out. ${ }^{9}$

Given the growing number of citizens with Muslim background this is hardly a statistic surprise. Rather, it must be construed as a beneficial development in terms of civic and professional involvement. It is, however, also a development that brings unexpected problems and challenges to light, for instance students' feelings of cultural estrangement and failure to decode the sometimes occult academic economy (economy in the sense of Bourdieu's cultural capital). To be sure not problems restricted to persons with Muslim 
background, but a problem of the late-modern mass-university. Our specific research focus does not encroach much upon the general demographic changes and challenges in academia, ${ }^{10}$ but will restrict itself to those fields that relate to Islam as an integral part of its research, teaching and curriculum. We also find that the issues of Muslim background and enrolment can (and should) generate some interesting questions to the field, some of which are standard quandaries with respect to religious subjects and some of which seem rather new to field. To mention a few: the classic emic-etic dilemma ${ }^{11}$ and the viability/acceptability of a more faith-based or -sensitive research (as in academic Christian or Jewish theological studies) versus scepticist or 'aggressive' approaches, the question of Orientalist agendas or other varieties of bias (religious, ideological, ethnic etc.), the question of academic independence and funding and so forth.

It would be one-sided only to focus on the rising number of academic stakeholders with Muslim background. This new demographic situation also exposes a process of academic bridging, namely between the 'old' stakeholders of Islamic studies (typically white, male non-Muslims) and the new stakeholders. Thus, we should be wary not to construe this study as a study in any kind of academic appropriation (by the new stakeholders) and marginalization (of old stakeholders), but rather as a process of bridging between two worlds previously decoupled, i.e., Academia and the Islamic world. This bridging process, however, may also entail a process of a new balance of power in an academic field hitherto rather low on Muslim staffing.

Now, the above-mentioned numerical observation was initially based on rather casual and occasional observations of the participants on the international academic scene, i.e., at conferences, in journals, anthologies, and monographs. Later, this observation was corroborated by conversations undertaken with scholars who have had yearlong experience in the field. Furthermore, scholars of Islam have begun to comment on this development in publications. Two quotes will shore up this claim. The first one is taken from Globalising Islam, written by political scientist and Islamism researcher Olivier Roy, where he calls attention to a new class of Muslims with high education:

Highly qualified professionals $[\ldots]$ and scholars are going from position to position according to market opportunities... An uprooted, deterritorialised and cosmopolitan intelligentsia, sharing a common language (English or, less often, modern literary Arabic), plays a role in producing values, teachings and world views adapted to globalisation... ${ }^{12}$ 
As already noted a small segment of this new transnational and cosmopolitan educational elite is also gaining foothold in Islamic studies.

The second quote brings up the issue of migration and is to be found in the preface to the latest landmark publication in Qur'ânic studies, i.e., The Encyclopaedia of the Qur'ân $(E Q)$. Here general editor Jane Dammen McAuliffe comments on what she perceives to be an accelerating bridging-process of the erstwhile gap between Muslim and European/Western scholarship: "But the "two solitudes" of Muslim and non-Muslim qur'anic studies are beginning to break open, at least on some occasions and within some contexts." (McAuliffe 2001: viii) In comparison with the two first editions of the mother-ship of Islamological scholarship, i.e., The Encyclopaedia of Islam (EI; respectively 19131938 and 1960-2005), this significant work in Qur'ânic studies is distinguished by its inclusion of scholars with a Muslim background. ${ }^{13}$ McAuliffe accounts for this development with reference to the migration setting:

Perhaps the most significant point of confluence, however, is graduate training and the production of new generations of doctoral degrees in the field of qur'anic studies. Increasingly, student pursuing graduate work in qur'anic studies, as well as other subfields of Islamic studies, in major universities in Europe, the United States, Canada and elsewhere are coming from immigrant Muslim families. Many of these are second or third generation products of post-colonial patterns of Muslim migration to Great Britain, France, Germany and North America. Consequently, most of these students enter graduate programs with an educational background and a set of academic assumptions that are indistinguishable from those of their non-Muslim peers (ibid.).

It goes without saying that we are do not unreservedly subscribe to McAuliffe's claim that the educational background and academic assumptions of these students are "indistinguishable" from those of their non-Muslim equals. Certainly, we do not presume any 'great divide' but we simply propose that we are more attentive to difference, perhaps even being affirmative about it.

Finally, our informed guesses and occasional observations on the new Muslim influx have been preliminarily honed by reports and statistical material, e.g., the Higher Education Funding Council for England's report on the Islamic studies provision, at higher educational level, within the UK. If we assume that the ethnic category Asian/Asian British primarily covers persons with Muslim background (persons of Pakistani and/or Indian descent but also persons with roots in other Asian Muslim countries, e.g., Malaysia and Indonesia), then we cannot but notice that this ethnic/religious group accounts for $43 \%$ 
of all Islamic studies students, ${ }^{14}$ compared with $5 \%$ of this category across related studies like theology and religious studies, philosophy, and archaeology. These numbers, of course, must vary from country to country, but the British numbers seem nonetheless an interesting indicator.

Our project is thus, grosso modo, a study in a very specific segment of the new Muslim elites, ${ }^{15}$ viz., the academic and intellectual. This new segment or 'class' of scholars faces the challenge of engaging in a time-honoured and prestigious institution, which includes a time-honoured Christian and humanistic legacy as well as a more strong secularist and historical-critical outlook. ${ }^{16}$ In a highly politicized climate they risk ending up being caught, as it were, between a rock a hard place; for instance by being charged with bias or apologetics from one side and being slandered as 'un-Islamic' or disloyal to their background from another side. Nonetheless, a substantial part of these scholars also possess some rather unique and advantageous assets, for instance near or full fluency in relevant languages (e.g., Arabic and Persian), a certain 'natural' knowledge of texts and traditions, and easier access to milieus suspicious of non-Muslims.

Who, then, are these new agents of academia? A number of them are internationally prominent scholars/exegetes/conférentiers who hold (or, have held) permanent or temporary positions at European and North American universities, inter alia, Nasr Hamid Abu Zayd, Fazlur Rahman, Ismail al-Faruqi, Mohammad Arkoun, Mohamed Talbi, Abdolkarim Sorush, Seyyed Hossein Nasr, Tariq Ramadan. Less known, but no less important, are those professors and lecturers with Muslim background who pursue their research in Islamic exegetical matters on a daily basis and within very specialist settings - and since this segment is more numerous in persons that that of the academic stars, we may hypothesise that their influence is broader and deeper than hitherto imagined. To be sure, these individuals' biographies, research fields, theories, methodologies, and formal academic careers are diverse, but they all, all things equal, enjoy a Muslim background. Converted and influential scholars working within Islamic studies, e.g., Timothy J. Winter, Amina Wadud, Neal Robinson, Anne Sofie Roald, Rosalind Ward Gwynne, can be said to hold a special position since they cannot by definition be categorized as scholars with a Muslim background. ${ }^{17}$ As already indicated, the term 'background' marks an important modifier in relation to the rather unmitigated confessional category 'Muslim., 18 
Thus, it would be something of an insinuation to let such a confessional category override the scholarly qualifications. Though matters of faith and confession are in principle of no relevance to the scholarship (and its purported ideals of objectivity) pursued, it is nonetheless of importance that the academic demography is getting more differentiated and more calibrated to people with a Muslim background. We do therefore not assume that background is irrelevant. Indeed, in the current politicized climate background has turned into an issue that - ironically - no longer can be relegated to the background.

Another important segment of actors to take into account concerns the students. Scholar-teachers do not reside in splendid isolation but engage in regular interaction with students, a rising number of which also have a Muslim background. Therefore, it is also crucial to take the Muslim students into account when investigating the current changes and states of affairs in Academia. As we are aware that a complex interplay of questions and answers takes place between scholars and students, we therefore hold that the present research project should also investigate the interplay as it takes place, first and foremost in the lecture hall but perhaps also during tutoring sessions. We should add here, that the presence of significant numbers of Muslim students probably also have an impact on non-Muslim teachers and their pedagogical arrangements. ${ }^{19}$

Simultaneous with this emerging segment of scholars and students with a Muslim background, a number of universities are also beginning to offer programmes in Islamic theology (e.g., interfaith relations, comparative religion), e.g., Birmingham (since 1976), Georgetown, Leiden, Münster, Cardiff, Johann Wolfgang Goethe-Universität Frankfurt. A few private Muslim initiatives with regard to higher education are also emerging, e.g., Islamische Universitet Rotterdam and Institut Européen des Sciences Humaines.

\section{Some Hypotheses}

It is highly conceivable that the structural and demographic developments at university level will also have wider and deeper implications for the exegetical shaping of Islam in a Western context - not only within the confines of academia but also outside, i.e., in the non-academic Muslim milieus and the public sphere at large. Such implications will probably also influence exegetical discourse in non-Western Muslim milieus. 
What kind of Islam and Islamic thinking could possibly develop over the next decades, when a growing percentage of scholars and students have a Muslim background? Could it usher in - or has it already been ushered in - intellectual and theological consequences similar to the ones that developed within Christian theology since the Age of Enlightenment and the Jewish Haskalah (i.e., the European Jewish variant of the Enlightenment)? Is a Wissenschaft des Islam (as an approximate equivalent to the erstwhile so-called Wissenschaft des Judentums) in the making? In other words: a new critical apparatus and receptivity regarding the normative text corpora of the Islamic tradition vis-à-vis Europe and the Western world at large.

One major hypothesis that we put forward with respect to this new segment of homo academicus concerns what some have termed "critical Islam" (Mandaville 2003: 127145) or "liberal Islam" (Kurzman 1998; Binder 1988). Such a critical Islam would be more willing to contextualize - and to a certain extent also relativize - doctrines and normative codes as well as being able to advance a more sceptical and heterogeneous conceptualization of "Islam" in all its width and depths. Ijtihâd, re-thinking and reconstruction, discovery and production of an ever expanding - yet also provisional knowledge remain some of the key words in this academic enterprise. Kurzman's "liberal Islam" is, according to himself, merely a heuristic term but one that frequently implies pro-democratic, pro-feminist, pro-freedom-of-speech, pro-human-rights principles.

We claim that the modern university institution provides one the most advanced and effective platforms for the articulation and dissemination of independent, original, and critical interpretations with regard to these issues. Interpretations that in all likelihood will come out as an important strand in the much debated question of a liberalization of (European) Islam (in Europe). ${ }^{20}$ To be sure, it amounts to a cliché to depict the modern scholar as the introvert 'odd fellow' out of touch with societal affairs. Rather, through teaching, sometimes through public debate and the increasing demand for public dissemination and outreach the contemporary scholar is confronted with a steady flow of a more affluent (in terms of social and cognitive capital) audience that reacts to the premises and issues of his or her scholarship.

It should, however, be noted that the current developments in academia are quite different compared to those of the Enlightenment and the early modern university - for one 
thing, the optimism on behalf of a fully transparent and neutral Rationality has been subject to severe criticism in contemporary late modernity. Thus, since the late 1960s it has been common practice among scholars in the humanities/social sciences to acknowledge and reflect upon issues of hegemony and bias pertinent to one's particular field of learning, with respect to early scientific foundations and motives as well as potential biases. This critical reflection went hand in hand with reflections on one's gender, race, beliefs and personal history in relation to one's research in order to be as circumspect as possible. Critical Theory, social constructionism, poststructuralism, post-colonial studies, gender studies and related theoretical developments have posed a serious challenge to any positivistic and universalistic conceptions of history. In terms of campus life and administration, legal initiatives like affirmative action (in terms of race, gender, and religion) as well as more or less heated debates on academic freedom, speech and behaviour codes have gained some kind of institutional prominence in chorus with these development. Within Islamic and Middle East studies, Edward Said's Foucault-inspired version of a critique of Male, White, Christian, hegemonic Rationality, aka Orientalism, has proved to hold a lasting (and controversial) influence on the study of Islam, continually churning out new critical thinkers, some of who are Muslims.

Hitherto, the bulk of research on Muslims in Europe and North America has been devoted to subjects that deal with cultural/religious adaptation, negotiations and identity building on a very broad scale, often with a strong emphasis on sociological and anthropological models and ways of investigation. Particular interest has been devoted to popular currents and patterns among the general Muslim public and various grass-root organizations and - to a lesser extent - on some of the new prominent Muslim intellectuals. While the project envisioned will not disregard these intellectual celebrities and their more and less ingenious outpourings, we hold that it is just as important to take into consideration their less known Muslim peers and locate their institutional and exegetical Sitz im Leben. Without doubt, a monograph like Western Muslims and the Future of Islam (Oxford UP, 2004) by Tariq Ramadan has attracted and stirred a larger circle of readers than, for instance, Wadad Kadi's and Munstansir Mir's co-written entry on "Literature and the Qur'ân" in $E Q$. The relative specialist status of the latter, however, must not be 
neglected; with its detailed dealings with the Qur'ânic text it perhaps able to make a lasting theological/scholarly impact.

To recapitulate: The present project strives to strike a new balance. It is devoted to intellectual history and Forschungsgeschichte within rather elitist academic milieus but its focus is less on the select academic names (like the renowned freethinkers and reformists mentioned above) but rather on the whole gamut of academic staff and student contingents.

\section{Methodology and Case Selection}

Specific methodological designs remain to be developed, but fieldwork at selected universities will constitute an important part of a 'reality check.' Qualitative interviews with stakeholders will be vital just as quantitative data collected from local university administrations and from national surveys.

Selecting the cases in terms of countries, universities and programmes rest primarily on a rough estimate of academic prominence and proliferation and international influence. Though these categories are hard to pin down we hold them to be of special importance in terms of academic power in relation to the study of Islam in the West. We consider the following countries to be particular important: the English speaking countries (Britain, USA, and Canada), the German speaking countries (Germany, Austria, Switzerland), the French speaking countries (France, Belgium, and Switzerland).

Selecting individuals raises some definitional issues. Religious studies have always struggled with the definition of religion in theoretical and methodological terms. Hence, it is no innocent task to try to define particular groups of religious practitioners, in casu Muslims. In our case, we prefer to use - at least in the definitional terms - the somewhat cumbersome expression 'academics with Muslim background.' The rationale behind this phraseology was explained in the beginning of this paper. Selecting individuals involves two formal components. The first one stipulates that in order to come into consideration, the relevant subjects must be affiliated with a university or research institution, either as students or postholders. The second component is consent, that is, the subject must agree to be categorized as 'persons with Muslim background.' In practice, we are in the process of producing a list of individuals by means of records available over the Internet (usually 
university homepages and their staff directories), and by means of normal scholarly updating (journals, books, Whos Whos and Encyclopaedias).

\section{Invitation to Feed-back}

Since this project is in the making, the author would very much welcome critique and suggestions. My email is tho@teol.ku.dk

\section{Bibliography}

Barrett, David B. (ed.) 1982: World Christian Encyclopedia. A comparative study of churches and religions in the modern world AD 1900-2000. Nairobi: Oxford University Press.

Abu-Rabi', Ibrahim M., 2006: The Blackwell Companion to Contemporary Islamic Thought, Oxford, Blackwell Publishing

Binder, Leonard, 1988: Islamic Liberalism: A Critique of Development Ideologies, Chicago, University of Chicago Press.

Bourdieu, Pierre, 1988: Homo Academicus, Cambridge, Polity Press.

Daun, H. and Geoffrey Walford, 2004: Educational strategies among Muslims in the context of Globalization: Some national case studies, Brill, Leiden.

Dudoignon, Stephane et al. (eds.), 2006: Intellectuals in the Modern Islamic World. Transmission, Transformation, Communication, Routledge, London.

Frank, David John and Jay Gabler, 2006: Reconstructing the University: Worldwide Shifts in Academia in the $20^{\text {th }}$ Century, Stanford University Press, Stanford.

Hefner, R. W. and M. Q. Zaman, 2007: Schooling Islam: the culture and politics of modern Muslim education, Princeton University Press, Princeton.

Jonker, G., 2002: Eine Wellenlänge zu Gott. Der 'Verband der Islamischen Kulturzentren' in Europa, Transcript Verlag, Bielefeld.

Kadi, Wadad and Mir, Mustansir, 2003: "Literature and the Qur'ân”, in: J.D. McAuliffe (ed.), Encyclopaedia of the Qur'ân, vol. 3 J-O, Brill, Leiden, 205-227.

Klausen, Jytte, 2005: The Islamic Challenge. Politics and Religion in Western Europe, Oxford. 
Klinkhammer, G., 2000: Moderne Formen islamischer Lebenführung. Eine qualitativempirische Untersuchung zur Religiösität sunnitisch geprägter Türkinnnen der zweiten Generation in Deutschland, Diagonal, Marburg.

Kurzman, Charles, 1998: Liberal Islam: A Sourcebook, Oxford University Press, Oxford. Mandaville, Peter, 2003: “Towards a Critical Islam: European Muslims and the Changing Boundaris of Transnational Religious Discourse", in: Stefano Allievi \& Jørgen S. Nielsen (eds.): Muslim Networks and Transnational Communities in and across Europe, Brill, Leiden.

McAuliffe, Jane Dammen, 2001: "Preface”, in: J.D. McAuliffe (ed.) Encyclopaedia of the Qur'ân, Brill, Leiden, i-xiii.

Nielsen, Jørgen S., 1992: Muslims in Western Europe, Edinburgh University Press, Edinburgh.

Peter, Frank, 2006:'Individualization and religious authority in Western European Islam”. In: Islam and Christian-Muslim Relation, vol. 17, no. 7, 105-118.

Qâdî, Wadad and Victor Billeh, 2007: Islam and Education. Myths and Truths. The University Of Chicago Press, Chicago.

Ramadan, Tariq, 2004: Western Muslims and the Future of Islam, Oxford, OUP.

Roy, Olivier, Globalised Islam: Fundamentalism, De-Territorialisation and the Search for a new Ummah, C. Hurst \& Co. Publishers, London.

Smith, Wilfred Cantwell, 1959: “Comparative religion: Whither - and why?”, in: Mircea Eliade and Joseph Kitagawa (eds.), The History of Religons: Essays in Methodology, University of Chicago Press, Chicago, 31-58.

Taji-Farouki, Suha (ed.) 2004: Modern Muslim Intellectuals and the Qur'an, OUP, Oxford.

Wheeler, Brannon M. (ed.), 2003: Teaching Islam (AAR Teaching Religious Studies Series), Oxford University Press, New York.

Thomas Hoffmann is postdoctoral fellow at CEIT, Centre for European Islamic Thought, University of Copenhagen. 
1 Included in the term 'hadith-related literature' are texts that deal with the subject of Muhammad, his companions and the sahabas of early Islam, most notably the sira-literature.

${ }^{2}$ For an update on contemporary Islamic thinking, cf. Abu-Rabi' 2006 and Dudoignon 2006.

${ }^{3}$ Being one of the founding scholars in the development of the 'Muslims in Western Europe'-field; cf. Nielsen 1992.

${ }^{4}$ Officially launched in October 2007.

${ }^{5}$ For an excellent survey of the recent research history of Muslim religious authority in Europe, see Peter 2006.

${ }^{6}$ In which we include Turkey and Iran.

${ }^{7}$ A desideratum pointed out by Frank Peter: 2006, 112.

${ }^{8}$ E.g., the multiple programmes initated by the Saudi prince and tycoon Alaweed Bin Talal: The Prince Alaweed Bin Talal Center for Muslim-Christian Understanding, Georgetown University; Prince Alaweed Bin Talal Islamic Studies Program at Harvard, Harvard University; HRH Prince Alaweed Bin Talal Centre of Islamic Studies, Cambridge University; The Prince Alaweed Bin Talal Centre for the Study of Islam in the Modern World, Edinburgh. Stiftungsprofessur Islamische Religion, Goethe Universität, Frankfurt am Main

${ }^{9}$ Cf. e.g., the Bill Rammell report (BR is Minister of Higher Education) Islam at universities in England: meeting the needs and investing in the future by Ataullah Siddiqui, the Islam on Campus conference in Edinburgh 2006, and the recent special issue "Islamic Studies in Higher Education" of Journal of Beliefs \& Values. Studies in Religion \& Education, Vol. 28, No. 3, December 2007

${ }^{10}$ It is not, however, only Islamic studies that undergo changes these years. Indeed, the university institution as such undergoes major changes, see e.g. Frank 2006.

${ }^{11}$ As for instance demonstrated in Wilfred Cantwell Smith's famous stipulation that "no statement about a religion is valid unless it can be acknowledged by that religion's believers." (Smith 1959: 53).

${ }^{12}$ Roy, Globalised Islam, p. 104

${ }^{13}$ With the commencement of the third edition of $E I$ (2007-), the bridging process ushered in by $E Q$ will probably repeat itself on an even grander scale.

${ }^{14}$ With $57 \%$ of first degree students.

${ }^{15}$ As such the project follows in the footprints of rising number of studies of "new Islamic elites" (Peter, 107), e.g., Klinkhammer 2000; Jonker 2003; Taji-Farouki 2004; Klausen 2005. The emergence of new segment in the academic elite may add new insights to elite-theory (cf. Pareto, Wright Mills, Putnam) and 'Bourdieudian' theories on Homo Academicus.

${ }^{16}$ As for the Christian legacy, recall, for instance, several esteemed North American universities, like Harvard (Puritan) and Georgetown (Catholic), or Jewish (Brandeis), and virtually all old European universities. The secularist outlook is, of course, of importance for the French universities. The historical-critical outlook and the ideals of the Enlightenment still constitute important guiding principles for all the universities.

${ }^{17}$ Although one could say that a Muslim background continually widens and deepens as they live as Muslims.

${ }^{18}$ If forced to push forward a definition of a Muslim, we would come very close to a kind of neo-murji'aposition, viz. that a Muslim is a Muslim as long as (s)he defines himself as such.

${ }^{19}$ See e,g. the discussions in Brannon M. Wheeler, 2003.

${ }^{20}$ See Peter 107. 